\title{
Szkoła jako przestrzeń współpracy i otwartości wobec dziecka z rzadką chorobą genetyczną
}

\begin{abstract}
STRESZCZENIE
Celem artykułu było przedstawienie głównych problemów związanych funkcjonowaniem dziecka z rzadką chorobą w szkole oraz pokazanie form wsparcia dziecku i jego rodzinie oferowanych przez szkołę. W tekście prezentuję wyniki badań przeprowadzonych metodą wywiadu narracyjnego wśród rodziców dzieci z rzadką chorobą genetyczną. Respondenci przedstawiają trudne wybory związane z wyborem szkoły oraz częstymi zmianami placówek edukacyjnych dla swoich dzieci. Ukazują także pozytywne przykłady wsparcia udzielanego dziecku choremu przez szkołę oraz wychowawców. Rodzice doceniają nawiązanie przez nauczycieli podmiotowej relacji z dzieckiem i z rodzicami, zapewnienie dziecku właściwej opieki podczas zajęć lekcyjnych, innowacyjność w nauczaniu oraz postawę otwartości, która jest przekazywana społeczności szkolnej.
\end{abstract}

\section{Słowa kluczowe:}

rodzina, dziecko z rzadką chorobą, szkoła, wsparcie

\begin{abstract}
The aim of the article was to present the main problems related to the functioning of a child with a rare disease at school and to show the forms of support for the child and his family offered by the school. In the text, I present the results of research carried out using the method of narrative interview among parents of children with a rare genetic disease. Respond-
\end{abstract}

1 Urszula Klajmon-Lech, Wydział Etnologii i Nauk o Edukacji, Uniwersytet Śląski w Katowicach, Polska, urszula.klajmon-lech@us.edu.pl 
ents present difficult choices related to the choice of school and frequent changes of educational facilities for their children. They also show positive examples of support provided to the child by the school and educators. Parents appreciate that the teachers establish a subjective relationship with the child and parents, provide the child with proper care during classes, innovate in teaching and the attitude of openness that is passed on to the school community.

\section{Keywords:}

family, child with a rare disease, school, support

\section{WPROWADZENIE}

Jedna z najistotniejszych kategorii poruszanych przez pedagogów i psychologów międzykulturowych - kategoria Innego dotyczy całej sfery egzystencji mającej związek z osobą, w której musi się ona odnaleźć (Rzeźnicka-Krupa, 2013, s. 41). Osoba, tworząc relacje, jest sobą w stosunku do innych osób. Równocześnie traktuje siebie samego jako innego, gdyż owa „osobność” jest warunkiem jej podmiotowości i człowieczeństwa. Inny postrzegany jest także jako każdy spotykany człowiek. W wyniku rozgraniczeń i różnego rodzaju kategoryzacji grupowych przejawiających się w tworzeniu podziałów, podejmowany jest wysiłek wprowadzenia „społecznego ładu” i strukturalizacji grup i osób. Daje to złudne poczucie bezpieczeństwa osobom narzucającym stygmaty i kategoryzacje wobec innych (Heine, 2001, s. 51-55). Inność pojmowana jest w tym kontekście jako obcość, a więc zjawisko nienależące do naszego świata, wykraczające poza zasady naszej interpretacji tego świata. Inny to osoba odmienna ze względu na przypisywane mu przez ludzi cechy czy atrybuty. Do takich atrybutów inności należą: inność kulturowa, religijna czy choroba - jako inność fizyczna, psychiczna lub intelektualna.

Z pewnością dziecko z rzadką chorobą genetyczną postrzegane jest jako inne, zwłaszcza wtedy, gdy otoczenie dostrzega oznaki tej choroby. Stygmatyzowanie go jako Innego jest charakterystyczne także dla środowiska uczniów - rówieśników oraz nauczycieli szkoły ogólnodostępnej. Szkoła spełniać może szczególną rolę w wychowaniu do dostrzegania i przyjmowania inności osoby chorej jako wartości. Pedagodzy pracujący w placówkach edukacyjnych - przedszkolach i szkołach ogólnodostępnych, szkołach integracyjnych oraz placówkach specjalnych stanowią także ważne źródło wsparcia dziecka oraz pedagogizacji jego rodziny.

W Unii Europejskiej chorobą rzadką (chorobą sierocą - ang. orphan disease) określa się jednostkę chorobową występującą nie częściej niż 5 na 10 tys. osób. 
Choroby rzadkie mają heterogenną symptomatologię, postępujący przebieg, różne, choć często niepomyślne rokowania. Większość z nich ma podłoże genetyczne (zakłada się, że jest to $80 \%$ tych chorób), zaś $75 \%$ tych schorzeń dotyka dzieci (Śmigiel, Łaczmańska, 2014, s. 14). Są to zazwyczaj choroby o charakterze przewlekłym, nieuleczalnym, wśród objawów wielu z nich znajduje się niepełnosprawność umysłowa w stopniu umiarkowanym, znacznym lub głębokim. Dotychczas zdefiniowano blisko 8 tys. chorób rzadkich, wiele pozostaje jednostkami bez nazwy. Szacuje się, że w Polsce choruje na nie około 2 mln osób.

W artykule ukazuję dobre praktyki i przykłady takich postaw nauczycieli oraz organizacji szkół, które wykazują wsparcie, otwartość i współpracę z dzieckiem chorym na rzadką chorobę genetyczną oraz jego rodzicami. Uczciwość badacza każe mi przyznać, że wyniki moich badań ukazują zdecydowanie więcej negatywnych przykładów - szkół i nauczycieli, którzy charakteryzują się postawą dyskryminacyjną i lekceważącą w stosunku do chorych uczniów, a także w stosunku do ich rodzin (Klajmon-Lech, 2018).

Pragnę odpowiedzieć na pytania: jak przebiega ścieżka edukacyjna dzieci z rzadkimi chorobami genetycznymi? Jakie działania szkoły oraz nauczycieli sprzyjają postrzeganiu przez rodziców szkoły jako miejsca przyjaznego dziecku i jego rodzinie?

\section{MATERIAŁ I METODY}

Prezentowane w artykule wyniki badań są częścią szerszego projektu badawczego realizowanego przeze mnie w latach 2014-2017, dotyczącego sytuacji rodziców dzieci z rzadkimi chorobami i skierowanych do tej grupy form wsparcia (Klajmon-Lech, 2018).

Celem badań było przedstawienie głównych problemów związanych funkcjonowaniem dziecka z rzadką chorobą w szkole oraz pokazanie form wsparcia dziecku i jego rodzinie oferowanych przez szkołę.

Zostało przeprowadzonych 26 wywiadów z 23 osobami (20 matkami oraz trzema ojcami)2 mieszkającymi w Polsce (w Warszawie, Wrocławiu, Białymstoku, Cieszynie, Ustroniu, Gdyni i innych miastach). Badano rodziców dzieci chorych na rzadkie choroby genetyczne (byli to rodzice dzieci znajdujących się w wieku szkolnym, jak i rodzice osób dorosłych - w wieku 23-33 lat). Dzieci badanych rodziców chorują na Zespół Pradera-Williego, Zespół łamliwego chromosomu X,

2 Trzech respondentów udzielało wywiadu dwukrotnie. 
Fenyloketonurię, Zespół Draveta oraz inne rzadkie zespoły genetyczne. Wszystkie zostały zdiagnozowane w Poradni Psychologiczno-Pedagogicznej jako osoby z umiarkowanym, znacznym lub głębokim stopniem niepełnosprawności umysłowej. Rodzice przed przystąpieniem do badania udzielali pisemnej zgody na jego przeprowadzenie.

Badania były prowadzone zgodnie z metodologią wywiadu narracyjnego (Schütze, 2012, s. 425). Długość wywiadów wahała się od 40 minut do 3 godzin. Były one nagrywane na dyktafon, poddawane transkrypcji, a następnie analizie: podziałowi tekstu na segmenty i subsegmenty, strukturalnemu opisowi zmierzającym do ustalenia procesów wynikających z narracji, analitycznej abstrakcji (Kos, 2004, s. 104-110; Kaźmierska, 1997, s. 69-70; Rieman, Schütze, 2012, s. 406-412).

W narracjach badanych rodziców wiele miejsca zajmowały opisy doświadczeń związanych z karierą edukacyjną chorych dzieci. Szkoła była dla badanych miejscem, od którego oczekuje się wsparcia nie tylko dla dziecka, lecz także dla całej rodziny.

\section{REZULTATY}

Analiza narracji pozwoliła wyodrębnić przedszkole, szkołę oraz inne placówki edukacyjne jako ważne kategorie w życiu badanych rodziców. Wspomnienia o szkole jako miejscu wsparcia (lub jego braku) chorego dziecka, o nauczycielach którzy stali się osobami znaczącymi dla rodziców, o relacjach pomiędzy szkołą a rodziną zajmują znaczną część opowieści badanych. Warto podkreślić, że wątek związany z edukacją szkolną dzieci był także poruszany we wspomnieniach rodziców dzieci dorosłych - dwudziesto- i trzydziestoletnich, co świadczy o znaczeniu, jakie przypisywali szkole w życiu swojego dziecka i własnej rodziny.

\subsection{TRUDNE DECYZJE RODZICÓW ZWIĄZANE Z WYBOREM ŚCIEŻKI EDUKACYJNEJ DLA SWOICH DZIECI}

Rzadkim chorobom genetycznym często towarzyszy niepełnosprawność psychoruchowa, dlatego intencją rodziców było szukanie placówki edukacyjnej, która spełniałaby potrzeby dziecka z niepełnosprawnością. Narracje rodziców dotyczące kariery edukacyjnej dzieci ukazują trudne wybory i dylematy, przed którymi wielokrotnie stali rodzice, żeby zapewnić swojemu dziecku placówkę, która będzie dostosowana do poziomu jego rozwoju i jego potrzeb. Czterech z badanych rodziców zdecydowało się na podjęcie działań społecznych we własnym środo- 
wisku gminnym czy miejskim w celu utworzenia przedszkola, szkoły czy klasy integracyjnej. Ich działania miały na celu dobro własnego dziecka i stworzenie mu najlepszych warunków rozwoju - wynikały z braku placówek odpowiednich dla dzieci z niepełnosprawnością w miejscu zamieszkania, zaś rodzice nie chcieli „skazywać” dziecko na dalekie dojazdy do szkoły.

Szkoła - według rodziców - ma stać się miejscem bezpiecznego rozwoju dziecka, a także środowiskiem mu przyjaznym w równym stopniu, co dom rodzinny:

Teraz jesteśmy na etapie szukania odpowiedniej szkoły, szkoły, która uszyta będzie na wymiar mojego dziecka. Burza mózgów, kombinacje alpejskie, co tu zrobić, żeby było dobrze dla niego, żeby nie burzyć poczucia bezpieczeństwa, bo to jest najważniejsze u B. (...) Chcemy taką szkołę dla niego znaleźć, szkołę, która jest przedłużeniem domu. (wywiad 14)

Analiza wyborów edukacyjnych dokonywanych przez rodziców w imieniu swojego dziecka chorującego na rzadką chorobę genetyczna pozwoliła wyodrębnić następujący schemat:

Przedszkole/szkoła ogólnodostępna

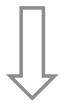

Szkoła integracyjna

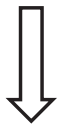

Nauczanie specjalne

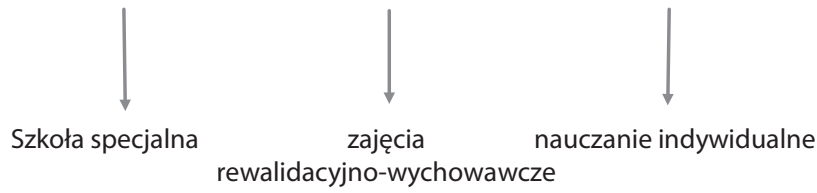

Rys. 1. Model wyborów edukacyjnych dokonywanych przez rodziców dla dzieci z rzadkimi chorobami genetycznymi Źródło: badania własne.

Charakterystyczne dla wszystkich badanych przeze mnie rodziców były częste zmiany placówek edukacyjnych. Decyzje z tym związane były, jak podkreślają badani, podyktowane troską o dobro dziecka i zauważonymi przez rodziców 
niepowodzeniami szkolnymi dziecka. Jak jest widoczne na schemacie, dzieci rozpoczynały edukację o charakterze włączającym (w szkole czy przedszkolu ogólnodostępnym), a następnie ich ścieżka edukacyjna kierowała się ku nauczaniu segregacyjnemu (w szkołach specjalnych, nauczaniu indywidualnym w domu lub na zajęciach rewalidacyjno-wychowawczych).

Dość szybko (już w przedszkolu, w klasie zerowej lub na etapie rozpoczęcia edukacji szkolnej) rodzice orientowali się, że dziecko nie potrafi sprostać wymaganiom szkoły ogólnodostępnej. Rodzice zostali postawieni przed decyzją wyboru kolejnej placówki edukacyjnej. Najczęściej decydowali się na szkołę o charakterze integracyjnym. W swoich biografiach rodzice relacjonowali rozczarowanie tego typu przedszkolem lub szkołą, niewłaściwą opieką (lub brakiem w ogóle jakiejkolwiek opieki) nad chorym dzieckiem, a najczęściej opacznie pojmowaną przez nauczycieli integracją:

W końcu się dostał, ale pani mi dała warunek, że ja muszę tam z P. być na tych wszystkich zajęciach. No i ja przychodziłam na ósmą, siedziałam tam do dwunastej. I to była tylko taka przechowalnia, gdzie ja się tylko P. zajmowałam, żadna pani nigdy do niego nie podeszła, żadna go pani nie wzięła za rękę i byliśmy tam cztery czy pięć miesięcy i zrezygnowałam, bo ja nie wyrabiałam psychicznie. (...) Pani kazała niepełnosprawnemu umysłowo dziecku - były takie książeczki dla dzieci cztero- i pięcioletnich. I pani mówi: „No to niech go pani posadzi do tego krzesełka i niech też to rozwiązuje!” A P. nawet wtedy nie umiał trzymać długopis. Ja mówię: „Ale jak on to ma rozwiązać? Jak on tego nie potrafi”, „No to niech pani to rozwiąże za niego, ale żeby było”. To był taki jeden przypadek, później drugi przypadek był w tym przedszkolu integracyjnym, dla mnie to jest porażka, pani mówi: „No to dzieci - teraz się bawimy”. I ona siada do biurka, pije kawę, a te dzieci gonią, normalnie, jakbyś ich wypuścił, jakby stado baranów. I ten P. był tym piskiem tak przerażony (...). Ja tak sobie pomyślałam: „Jak on by tam był sam, to co ta pani zrobi? Nic! Kompletnie nic!”. I przez te kilka miesięcy, kiedy byłam z P. w tym przedszkolu, nigdy żadna pani nie powiedziała mi: „Proszę mi dać P., ja z nim pójdę” albo „Proszę iść sobie siąść, ja sobie z nim zrobię”. (...) No ale chodziłam dalej, bo chciałam, żeby P. miał kontakt z rówieśnikami. Czy żeśmy szli na spacer, to pani łączyła w pary - ja zawsze byłam z P., nigdy nie dała go z jakimś innym dzieckiem, ale któregoś razu puściłam jego rękę i myślę: „No ciekawe, co ta pani zrobi?” Wzięłam inne dziecko za rękę i podeszłam do takiego chłopczyka, pamiętam do dzisiaj jego buzię, fajny chłopczyk, myślę nawet nieświadomy tego, co mówił. I pani mówi: „Proszę 
złapać P. za rękę!” A ten chłopczyk odpowiedział (...), że on nie będzie szedł z głupkiem. (...) Nigdy nie miałam do niego pretensji, bo to są dzieci, te dzieci mówią to, do czego są nauczeni. Ale tak sobie myślę, że niewiele było spotkań z rodzicami zdrowych dzieci. Te dzieci były eliminowane przez te zdrowe dzieci i było to widać, jak się tam siedziało po cztery, pięć godzin, to było to widać. Te dzieci się nie bawiły z naszymi dziećmi. (...) Myślę, że takie przedszkole integracyjne to jest tylko na papierku, teoretycznie, a w praktyce to jest przedszkole nieintegracyjne. (wywiad 11)

Przyczyną kolejnych wyborów dotyczących zmiany szkoły były głównie niepowodzenia edukacyjne. Często jednak rodzice opisywali niewłaściwe traktowanie przez nauczycieli dziecka, brak reagowania na szykanowanie go ze strony rówieśników, zamknięcie i brak współpracy z nimi, co stawało się bezpośrednim powodem kolejnych poszukiwań „,szkoły szytej na miarę” choroby dziecka. Rodzice podejmowali następny krok, decydując się na wybór szkolnictwa specjalnego i dobór odpowiedniego dla dziecka nauczania: szkoły specjalnej z oddziałami dla uczniów z niepełnosprawnością intelektualną w stopniu lekkim, specjalnego ośrodka szkolno-rewalidacyjno-wychowawczego (a w ich ramach tzw. szkoła życia) lub nauczania indywidualnego. Ta decyzja była oceniana przez badanych rodziców jako trafna. Dzieci wreszcie odnajdywały swoje miejsce - w środowisku osób z głębszą niepełnosprawnością psychoruchową.

\subsection{DOBRE PRAKTYKI SZKOŁY W STOSUNKU DO UCZNIÓW Z RZADKĄ CHOROBĄ}

Choć szkoły i nauczyciele byli najczęściej oceniani negatywnie, pragnę przedstawić te wypowiedzi rodziców, które opisują szkoły jako miejsce wsparcia dziecka i całej rodziny. Moim zamierzeniem jest tym samym podjąć refleksję nad tym, jakie działania i postawy sprzyjają postrzeganiu przez rodziców szkoły jako miejsca przyjaznego dziecku choremu.

Rodzice wysoko cenili te zajęcia szkolne, w których uczniowie zdobywali podstawowe umiejętności: poznawcze, motoryczne, komunikacyjne, społeczne, a także z zakresu samoobsługi. Uczenie chorego dziecka podstawowych czynności stanowiło wyzwanie przekraczające ich kompetencje, dlatego doceniali rolę szkoły w tym zakresie:

Bardzo dużo się tam nauczył. Duży przeskok w porównaniu z tym, co wcześniej w domu. Bo wiadomo, nauczył się samodzielności w jedzeniu, w korzystaniu z toalety. (wywiad 12) 
Ważne było także dla nich zaangażowanie nauczycieli i wychowawców w swoją pracę, nawiązanie przez nich podmiotowej relacji zarówno z dzieckiem, jak i z rodzicami oraz zapewnienie dziecku bezpieczeństwa:

Tutaj cały czas coś się dzieje. Tutaj nauczyciele i dyrektorka angażują się w różne akcje na sto procent. (...) Te jakieś jasełka, te festyny, wyjazdy, wszystko to mi się bardzo podoba. (wywiad 12)

B. był w tej szkole integracyjnej (...) 5 lat. Tam ich jest gdzieś pięćdziesięcioro. Wszyscy się tam znają, wszyscy o wszystkim wiedzą, poprzez rehabilitantów, poprzez panie woźne - wszyscy pilnują tych dzieci, nie to że pilnują jak żandarmi. (...) Jeśli się coś zadzieje, to wszyscy wszystko wiedzą. Jakieś niepokojące zachowania, to wszystko jest na bieżąco załatwiane, bo wiadomo, jak to w szkole integracyjnej, gdzie są dzieci zdrowe i chore. Jest też tam dziewczynka z zespołem Aspergera. Ona też dojeżdża autobusem i też powoduje różne niepokojące sytuacje i to jest wszystko na bieżąco załatwiane. Ze względu na to, że dzieci jest mało i wszyscy się pilnują. (wywiad 5)

Dobry nauczyciel cechuje się według narratorów empatią i zrozumieniem nie tylko ucznia, ale także jego rodziców i ich potrzeb oraz oczekiwań. Jedna z matek opisała sytuację, kiedy została zmuszona do szybkiego znalezienia innej placówki edukacyjnej dla swojego syna. Wtedy nauczycielka zaproponowała jej pomoc:

Dyrektorka szkoły dała mi długą listę szkół życia i mówi: „Proszę sobie znaleźć”. A nauczycielka mojego syna mówi: „Jeśli pani chce, to ja z panią pojeżdżę i najwyżej zostanę z M., żeby pani sobie mogła wejść, pooglądać i porozmawiać z dyrektorem. I wtedy którą́ z tych szkół pani wybierze”. Wielki szacunek dla tej nauczycielki, która swój prywatny czas chciała poświęcić dla mnie i dla mojego syna. I tak też zrobiliśmy. Dzięki niej wybrałam szkołę, bo miałam ten komfort, że mogłam sobie na spokojnie je pooglądać, jeszcze się z nią porozumieć i spytać o jej zdanie jako pedagoga specjalnego, bo ona też jak mogła, to weszła i oglądała te szkoły. (wywiad 21)

Matka dziecka z Zespołem Pradera-Williego (którego najważniejszą cechą jest niepohamowany apetyt dziecka) przedstawiła wzorcowe środowisko szkolne swojego syna. Nauczyciel-wychowawca wprowadził dziecko w świat szkoły, jednocześnie uświadamiając wszystkim uczniom ich odpowiedzialność za chorego kolegę. Rówieśnicy wiedzieli, że nie mogą go częstować jedzeniem, gdyż może to mieć bardzo poważne konsekwencje dla jego zdrowia. Podjęli odpowiedzialność 
za swojego kolegę, współpracując zarówno z nauczycielem, jak i matką dziecka (wywiad 15).

W swoich narracjach rodzice docenili w nauczycielach traktowanie swojej pracy nie tylko w kategoriach obowiązku, lecz także jako powołania. Ważne dla nich było także dostosowywanie wymagań edukacyjnych do indywidualnych możliwości i potrzeb dziecka. Wobec potrzeby poznawania nowych metod i technik terapeutycznych i edukacyjnych, cenili w nauczycielach i dyrektorach szkół umiejętność nawiązania z nimi współpracy.

\section{DYSKUSJA}

Uzyskane wyniki badań dotyczące ścieżki edukacyjnej wybieranej przez rodziców dla dzieci z rzadką chorobą genetyczną - ukazujące tendencję w kierunku od edukacji włączającej ku segregacyjnej, czyli przenoszenia dzieci ze szkół ogólnodostępnych i integracyjnych do szkół specjalnych, potwierdzają badania przeprowadzone przez naukowców z Instytutu Badań Edukacyjnych w polskich szkołach oraz wśród rodziców w 2014 r. Autorzy raportu wykazują, że większość rodziców dzieci z niepełnosprawnością deklaruje chęć przeniesienia dziecka do szkoły specjalnej, gdyż jest to dla nich łatwiejsza opcja niż walka o zapewnienie mu dobrych warunków w szkole ogólnodostępnej. Rodzice obserwują niechęć nauczycieli i dyrektorów szkół wobec dzieci chorych i z niepełnosprawnościami, czasem wręcz działania prowadzące do „pozbywania się niewygodnych uczniów”. Zwiększona subwencja oświatowa (czasem dziesięciokrotnie wyższa niż na dzieci zdrowe), którą przekazuje rząd na niepełnosprawnych uczniów, wciąż nie jest przekazywana - mimo zmian w prawie - na wsparcie dla konkretnego dziecka. Wymienione mankamenty w funkcjonowaniu polskich szkół ogólnodostępnych skutkują tym, że dzieci niepełnosprawne nie wykorzystują w pełni swojego potencjału, nie mają szans skonfrontować swojej niepełnosprawności ze światem zewnętrznym i nie integrują się ze społeczeństwem, a w przyszłości mają nikłe szanse na rynku pracy (Grzelak, Kubicki, Orłowska, 2015, s. 36-89).

Decyzje, które podejmowali rodzice na początku ścieżki edukacyjnej własnych dzieci z rzadką chorobą genetyczną (umieszczanie ich w przedszkolu, klasie zerowej, w początkowym etapie szkoły podstawowej w tzw. palcówkach ogólnodostępnych) wiązały się z niezakończonym na tym etapie procesie adaptacji sytuacji przez rodziców. Rodzice w pierwszych latach życia dziecka nie byli pogodzeni z jego chorobą, zaprzeczali jej, stosowali różnorakie mechanizmy obronne, do których należy nieuznawanie faktu niepełnosprawności dziecka, jego upośledzenia 
umysłowego (Twardowski 1995, s. 24). Jak wyjaśnia Małgorzata Kościelska (2000, s. 192), mogą oni wybierać działania związane z deformacjami percepcyjnymi. Aby uchronić się przed bólem związanym z uznaniem własnego dziecka za upośledzone, rodzice podejmują próby nieprzyjęcia tej informacji do wiadomości. Zaprzeczają diagnozie, deprecjonują doświadczenie i wiedzę specjalistów, poszukują innych, którzy mogą dać im „łagodniejszy wyrok”. Wyrazem zaprzeczenia jest wybór szkoły, która jest ogólnodostępna, „dla normalnych dzieci”.

Początkowe decyzje rodziców związane z edukacją włączającą swoich chorych dzieci mogły być także podyktowane brakiem diagnozy medycznej. Zdiagnozowanie rzadkiej choroby jest procesem żmudnym, w wielu przypadkach trwa nawet kilka lat. Jak przekazują narratorzy - także lekarze pierwszego kontaktu - pediatrzy, a także specjaliści pracujący w szkołach i poradniach pedagogiczno-psychologicznych lekceważyli objawy choroby i niepełnosprawności dzieci, przyczyniając się do błędnych decyzji rodziców związanych z edukacją dzieci.

Przedstawione w artykule dobre praktyki szkoły, nauczycieli i wychowawców wobec dzieci z rzadką chorobą genetyczną stanowią przykład wprowadzenia w życie praw osób chorych i niepełnosprawnych do bycia traktowanymi z szacunkiem należnym wszystkim członkom społeczeństwa oraz do umożliwienia im, dzięki odpowiedniemu wsparciu optymalnego rozwoju, edukacji i funkcjonowania w społeczeństwie. Takie działania określane są mianem normalizacji (Wolfensberger, 1972).

W edukacji włączającej oraz integracyjnej dużego znaczenia nabiera poszukiwanie skutecznych metod nauczania opartych na umiejętności kooperacji, dobra organizacja pracy lekcji z dzieckiem chorym, tworzenie kontekstu dla doskonalenia wspierającego oraz umiejętność rozwiązywania problemów, które pojawiają się podczas pracy dziećmi (Loska, 2004). Nauczyciele powinni dawać wsparcie uczniom poprzez poznanie specyfiki rzadkiej choroby, znajomość procedur medycznych wymagających wykonania ich w trakcie pobytu w szkole, znajomość specjalnych potrzeb dietetycznych dziecka (Brudnik, 2008, s. 13-15). Czynnikami ułatwiającymi choremu dziecku pobyt w szkole są: przyjazna postawa i otwartość nauczycieli, wysokie kompetencje zawodowe nauczyciela, dobra znajomość ucznia - także jego problemów zdrowotnych, umiejętność włączenia chorego dziecka w życie klasy, zadbanie o edukację rówieśników i uświadomienie im konsekwencji choroby tak, aby czuli się oni odpowiedzialni za swojego kolegę. 


\section{ZAKOŃCZENIE}

Sytuację dziecka z rzadką chorobą genetyczną i jego rodziny można określić jako szczególnie trudną ze względu na brak wiedzy najbliższych dziecka na temat jego rozwoju i perspektyw w przyszłości, niedostatek terapii i odpowiednich form leczenia, występowanie chorób towarzyszących u dziecka, a także niepełnosprawności psychoruchowej. Wsparcie społeczne, szczególnie pedagogiczne, które mogą zapewnić nauczyciele i wychowawcy w szkole jest ważną formą pomocy dla tej grupy osób. Nie zawsze jednak rodzina z dzieckiem chorym otoczona jest życzliwością, zrozumieniem i pomocą. Stąd częste zmiany w doborze placówki edukacyjnej dla dziecka dokonywane przez rodziców. Zmiany te nie służą uczniowi ani jego najbliższym.

Nadzieją napawają doniesienia niektórych rodziców na temat wzorcowej działalności wybranych szkół oraz pracujących w nich pedagogów. Rodzice najbardziej cenią w nich profesjonalne przygotowanie do pracy z dzieckiem ze specjalnymi potrzebami, ale także traktowanie zawodu nauczyciela jako powołania. Dobry nauczyciel to osoba, która jest otwarta na potrzeby zarówno dziecka, jak i jego rodziców. Doskonale ilustruje te cechy nauczyciela wypowiedź jednej z matek:

I uważam, że byłoby super, żeby ludzie się kształcili i żeby byli pedagogami, psychologami, żeby byli tymi nauczycielami wspomagającymi, żeby chcieli robić to, dlatego, że uważają, że jest to fajne. A jeżeli uważają, że się pomylili, to uważam, że się nie powinni wstydzić. Do zawodu nauczyciela dla naszych dzieci trzeba mieć powołanie. Nie każdy go ma. (wywiad 7)

\section{Bibliografia}

Brudnik, M. (2008). Współpraca nauczyciela wf-u z rodzicami uczniów o specjalnych potrzebach edukacyjnych. Wychowanie Fizyczne i Zdrowotne, 10, 13-15.

Grzelak, P., Kubicki, P., Orłowska, M. (2014). Realizacja badania ścieżek edukacyjnych niepełnosprawnych dzieci, uczniów i absolwentów - raport końcowy. Warszawa: Wyd. IBE.

Heine, M. (2001). Problemy integracji społecznej osób niepełnosprawnych. Zielona Góra: Wyd. UZ.

Kaźmierska, K. (1997). Wywiad narracyjny - technika i pojęcia analityczne. W: M. Czyżewski, A. Piotrowski, A. Rokuszewska-Pawełek (red.), Biografia a tożsamość narodowa (s. 329-330). Łódź: Wyd. Katedra Socjologii Kultury.

Klajmon-Lech, U. (2013). Pedagogizacja rodziców dzieci niepełnosprawnych. W: A. Weissbrot-Koziarska, I. Dąbrowska-Jabłońska (red.), Słownik metod, technik i form pracy 
socjalnej, opiekuńczej i terapeutycznej, 2 (s. 100-102). Opole: Wyd. Uniwersytet Opolski.

Klajmon-Lech, U. (2018). Trajektoria życia rodziców dzieci z rzadkimi chorobami genetycznymi. Formy społecznego wsparcia. Toruń: Wyd. Adam Marszałek.

Kos, E. (2013). Wywiad narracyjny jako metoda badań empirycznych. W: D. Urbaniak-Zając, E. Kos (red.), Badania jakościowe w pedagogice (s. 91-104). Warszawa: PWN.

Kościelska, M. (2000). Oblicza upośledzenia. Warszawa: PWN.

Loska, M. (2004). Leczenie, wychowanie i kształcenie dzieci przewlekle chorych oraz z uszkodzonym narządem ruchu. W: D. Piekut-Brodzka, J. Kuczyńska-Kwapisz (red.), Pedagogika specjalna dla pracowników socjalnych (s. 55-165). Warszawa: Wydawnictwo APS im. Marii Grzegorzewskiej.

Riemann, G., Schütze, F. (2012). „Trajektoria” jako podstawowa koncepcja teoretyczna w analizach cierpienia i bezładnych procesów społecznych. W: K. Kaźmierska (red.), Metoda biograficzna w socjologii (s. 389-415). Kraków: Wyd. Nomos.

Rzeźnicka-Krupa, J. (2013). Inny i pedagogika. Doświadczanie inności i relacje z innym jako istotne kategorie nauk o wychowaniu. Studia Edukacyjne, 28, 31-45.

Schütze, F. (2012). Trajektorie cierpienia jako przedmiot badań socjologii interpretatywnej. W: K. Kaźmierska (red.), Metoda biograficzna w socjologii. Antologia tekstów (s. 415-458). Kraków: Wyd. Nomos.

Śmigiel, R., Łaczmańska, I. (2012). Podstawowa wiedza potrzebna do zrozumienia chorób genetycznych. W: T. Kaczan, R. Śmigiel (red.), Wczesna interwencja i wspomaganie rozwoju u dzieci z chorobami genetycznymi (s. 11-34). Kraków: Wyd. Impuls.

Twardowski, A. (1995). Sytuacja rodzin dzieci niepełnosprawnych. W: I. Obuchowska (red.), Dziecko niepetnosprawne w rodzinie (s. 18-54). Warszawa: WSiP.

Wolfensberger, W. (1972). The Principles of Normalization in Human Services. Toronto: National Institute on Mental Retardation. 